Copyright (C) 2014 by Academic Publishing House Researcher

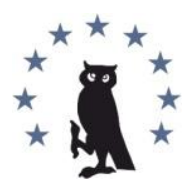

Published in the Russian Federation

European Researcher

Has been issued since 2010.

ISSN 2219-8229

E-ISSN 2224-0136

Vol. 83, No. 9-2, pp. 1694-1706, 2014

DOI: 10.13187/er.2014.83.1694

www.erjournal.ru

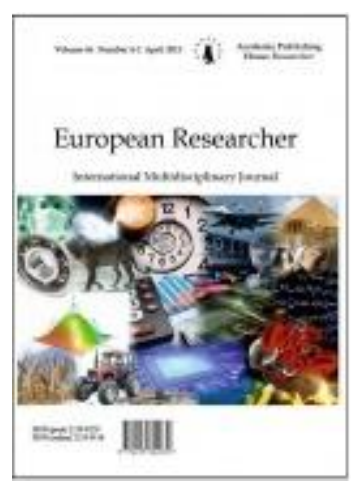

Economic sciences

Экономические науки

\title{
Determinants of Trade Credit: The Case of a Developing Economy
}

\author{
${ }^{1}$ Jaleel Ahmed \\ ${ }^{2}$ Hui Xiaofeng \\ 3 Jaweria Khalid
}

\begin{abstract}
1-3 School of Management, Harbin Institute of Technology, Harbin 150001, P.R China Corresponding author: Jaleelahmed11@yahoo.com
\end{abstract}

\begin{abstract}
This study answers the call of understanding trade credit determinants and consequences in different cultures and economic setups in order to be able to devise policies. Trade credit is affected by two types of factors including firm specific characteristics and macroeconomic conditions. This study tries to investigate the following firm specific variables such as firm size, liquidity, product quality, price discrimination, inventory and sales growth and found them significantly related to trade credit. Gross Domestic Product (GDP) is the variable which is used as macroeconomic variable and found positively related to trade credit. After collecting seven years data from 2005 to 2011 from non-financial firms of Pakistan, we have applied three models named, pooled ordinary least square method, fixed effects $m$ ethod and random effects method for estimation to reach at the conclusion that which model is more appropriate for this study based on panel data. F-test and Hausman test are used to compare the estimated models and they give their justification in favor of fixed effects model.
\end{abstract}

Keywords: Credit policy; trade credit; developing economy; bank credit; KSE.

\section{Introduction}

Organizations seek various means to finance their capital needs. Theorists has classified two major types of financing modes naming long term financing and short term financing. Constraints in accessing bank short term loans make other modes of short term financing more attractive. These problems are mainly due to the agency costs and information asymmetries as suggested by the economic theorists. Short term financing like trade credit resolves these issues and making it preferable or substitute to bank financing. Trade credit and bank loans are considered as substitute to each other as in tight monetary conditions, the share of trade credit in external financing policy is increased as compared to banks loans (Guariglia and Mateut 2006).

Trade credit, as explained by Martínez-Sola et al. (2012) is an arrangement between a seller and a buyer allowing an exchange of goods with deferred payment terms. Hence trade credit is an important source of financing for firms, especially for the small and medium sized firms (Boyery 
and Gobert 2007). Trade credit is general term that is used for either supply or demand for credit goods. When it appears on the assets side of the balance sheet it is called accounts receivables (trade credit supply). Alternatively, when trade credit appears at the liability side is referred to as accounts payable (trade credit demand). Trade credit enhances efficiencies on both sellers' and buyers' part by smoothing out the uncertainties in delivery cycles and simplifying cash management (Schwartz 1974).

Financial advantages that add to supply of trade credit enlists as the suppliers can easily and efficiently evaluate the financial standings and creditworthiness of their customers from close business ties and the power they possess over their customers by controlling the supply of goods in case of late payments or default (Ono 2001). Further, Smith (1987) argues that the firms forgoing the discount signals for a weak financial standing and calls for close monitoring by suppliers.

Further, Wilson and Summers (2002) suggest that trade credit proves to be an important marketing tool. The logic is that trade credit could be used to build business relationships in a new market and new entrants could earn success more easily as compared to building their reputation after years of hard work and marketing their products.

It is for these and many other positive reasons that evidence proves of strong use of trade credit in many developed and developing economies. The aggregate volume of trade credit was a significant part (17.8\%) of total assets for all American firms in the early 1990s (Rajan and Zingales 1995) while in the United Kingdom $70 \%$ of total short-term debt and 55\% of total credit received by firms is made up of trade credit (Kohler et al. 2000; Guariglia and Mateut 2006). Trade credit represents more than a quarter of total corporate assets in France, Germany and Italy and it is also important in emerging economies, like China, where firms get limited support from the banking system (Ge and Qiu 2007). The gap of research remains when the trade credit literature is sought for Pakistan. No study till date had carried out a detailed analysis of the factors effecting trade credit in non-financial firms listed at Karachi Stock Exchange (KSE), the country's largest stock exchange. Main objective of this research paper is to explore the major factors that determine the level of trade credit in listed non-financial firms of Pakistan.

Martínez-Sola et al. (2012) calls for a research on trade credit and firm characteristics in different cultures, as culture have a profound effect on the factors that govern the patters of trade credit. This research will contribute to the literature regarding the factors that influence the optimal quantity of trade credit in a developing country Pakistan.

The remainder of this paper is planned as section 2 reviews the literature that leads us to the gap in the literature and building of hypotheses. Section 3 discusses the sample and empirical methodology. Section 4 reports the results with the analysis and lastly section 5 concludes the study and discusses the implications of the findings.

\section{Literature Review}

Many researchers have investigated the determinants of trade credit with respect to their countries to analyze the importance and use of trade credit (Niskanen and Niskanen, 2006; Cheng and Pike 2003; Petersen and Rajan 1997).

In every corporate financing policy trade credit always performs a significant job. Funds involved in trade credit supply have always been considered as an investment in current assets. According to Giannetti et al. (2003) account of trade credit supply stands as a quarter of total assets in balance sheet of European firms. Trade credit is the major source of external financing in underdeveloped countries because they have less access to standardized capital markets (Beck et al. 2008; Ge \& Qiu 2007). Creditworthy firms use trade credit as an external source of financing and find it cheaper because they always seek a discount in early payments to suppliers (Giannetti et al. 2003).

Jain (2001) argued that trade credit act as a second flash cover between the relationship of financial institutions and businesses. In case of inefficient financial market it is quiet beneficial for buyers and suppliers to use this second layer to meet their external financing needs (Frank \& Maksimovic, 2004). Firms having less credible relation with financial institutions involved more in credit transactions and have enough amount of trade credit in their balance sheet than the firms having good association (Petersen and Rajan 1994).

1 Theoretical Background

The question arises why suppliers and buyers are willing to get involved in credit transactions 
whenever they know about other financing channels like bank credit that are more cheaper than trade credit. Literature on trade credit has tried to find out the motives at work in the supply and demand of trade credit. The theories that address some of these motives have explained below.

1.1 Financial Models

Trade credit serves as a monitoring tool for the product quality and shortens the informational asymmetries (Smith 1987; Long et al. 1993; Pike et al. 2005) regarding the quality of the delivered product between buyers and suppliers. This specially is of importance in a scenario where product quality verification needs longer time period (Smith 1987). Thus trade credit serves as a means to guarantee product quality by the suppliers (Lee and Stol 1993; Long et al. 1993; Deloof and Jagers 1996) and buyers could use trade credit as a mechanism to control purchased product quality (Smith 1987; Long et al. 1993). Due to this very reason, trade credit helps in shaping the buyer and supplier relationship towards a long term orientation ( $\mathrm{Ng}$ et al. 1999; Wilner 2000). This motive leads us to investigate the proxy for product quality that is TURN. This means that more the sales turnover, lesser would be the supply of trade credit because this would be the case when the product quality is not good or according to the buyers requirements. So the first hypothesis is

H1: There is a negative and significant relationship between TURN and trade credit supply.

1.2 Price Discrimination Theory

Trade credit is also used as a tool to design product pricing by sellers and thus, enhancing product demand. This could be done in two ways; either increasing cash discount or by extending credit period that ultimately results in hype in sales (Pike et al. 2005). All these setups results in price discrimination applied by sellers. As the theory of price discrimination put forward by Petersen and Rajan (1997) there are two types of customers one who would make an early payment for their purchases and the other who would delay. Thus the price discrimination allows suppliers to facilitate for repayment to both customers. This theory of price discrimination is widely supported in trade credit literature (Garcia-Teruel and Martinez-Solano 2010a; Guariglia and Mateut 2006).

From this theory we have drawn the variable of price discrimination which is also the measure of market power. Firms having unique products and larger operating margins may generate additional cash flows by offering their additional units to customers having weak financial standing on credit. As the strong customers may pay early against the weak ones, firms are thus able to discriminate price easily. This leads to the second hypothesis

H2: There is a negative and significant relationship between price discrimination and trade credit supply.

1.3 Transaction Cost Theory and Inventory Management Model

Transaction cost is considered as one of the motives that why suppliers and buyers are willing to involved in trade credit transactions. The theory put forward by Ferris (1981) suggests that trade credit could also be used a means to reduce transaction costs. Theory suggests that as the suppliers are able to separate items sold from cash in return, they could thus manage their future cash inflows and hence do not need to withhold surplus deterrent cash.

Inventory management model developed by Bougheas et al. (2009) states three variables naming inventory, liquidity and size of the firm in determining the level of trade credit. They argue that producers produce goods, either sell finished goods or holds them in inventory at cost and thus play a role in the credit chain as middle man. Vaidya (2011) has mentioned that sellers can shrink their finished goods inventory by contributing in credit sales. From this point of view are expecting an inverse relationship between trade supply and firm inventory. supply.

H3a: There is a negative and significant relationship between inventory and trade credit

It appears that firms having liquidity issues would extend more trade credit to their customers in order to have accounts receivables mounted which they may then use as assets or collaterals to banks. On the other hand firms which are in short of liquidity are expected to take more credit from their suppliers. Hence the hypothesis regarding liquidity and trade credit is as follows;

$\mathrm{H}_{3}$ b: There is negative and significant relationship between liquidity and trade credit supply. demand.

H3c: There is a positive and significant relationship between liquidity and trade credit 
Further, the inventory management model speaks that large firms do not face liquidity issues and do not have much storage cost of holding inventory like the small firm. This fact leads the small firms to resolve their issues of liquidity and inventory cost by granting more trade credit. Also as argued by Long et al. (1993) large firms normally have good reputation and creditworthiness so they have the capacity to get financing from any other source. They have less incentive to involve in credit sales and purchases. Large firms have no need to provide the guarantee for their products (Long et al. 1993). Hence we postulate the hypothesis regarding firm's size as follows; supply.

H3d: There is a negative and significant relationship between firm size and trade credit

H3e: There is a negative and significant relationship between firm size and trade credit demand.

Firms use trade credit to achieve their targets about growth (Niskanen and Niskanen 2006). Sales are the basic indicator of growth. A firm that is willing to increase its growth may seek to improve its sales. It can grant more credit on its sales to attract more customers which will lead to increase in sales. On the other hand, firms which are new in their businesses or facing some problems to acquire credit from other channels can also increase its sales by receiving more goods on credit from their suppliers. On the basis of these arguments we are expecting a positive relationship between sales growth and trade credit. supply.

$\mathrm{H}_{3}$ : There is positive and significant relationship between sales growth and trade credit

H3g: There is a positive and significant relationship between sales growth and trade credit demand.

1.4 Macroeconomic Conditions

A macroeconomic factor is gross domestic product (GDP). Smith (1987) and Walker (1991) advocates that the level of trade credit is settled on the conditions of economy. Firms normally increase the use of trade credit under the conditions of deteriorating in gross domestic product (Niskanen and Niskanen 2006). After finding a negative and insignificant relationship between GDP and trade credit they have mentioned that the results of this variable are difficult to explain. Therefore, we postulate the last hypothesis as under;

H4a: There is a positive and significant relationship between gross domestic product and trade credit supply

H4b: There is a positive and significant relationship between gross domestic product and trade credit demand

\section{Data Analysis and Econometric Methodology}

1 Data Analysis

We have used seven years data from 2005 to 2011 for analysis of determinants of trade credit for non-financial firms in Pakistan. Major part of data has been extracted from Balance Sheet Analysis (BSA) and Financial Statement Analysis (FSA) published by State Bank of Pakistan (SBP). Secondly, data have been extracted from the financial statements of non-financial firms listed at Karachi Stock Exchange (KSE). During the analysis firms which do not provide the complete information regarding trade credit supply, demand and other variables were excluded. Firms having missing and extreme values of assets and liabilities were also excluded.

The following Table 1 is showing the industrial distribution and their contributions in overall sample selected. We have selected the data from all non-financial firms listed at Karachi Stock Exchange (KSE) and then divide them into twelve main economic groups.

Table 1: Industrial Frequency Distribution

\begin{tabular}{|l|l|l|l|}
\hline No. & Sectors & Frequency & Percentage \\
\hline 1 & Textile & 155 & $38.85 \%$ \\
\hline 2 & Food & 54 & 13.53 \\
\hline 3 & $\begin{array}{l}\text { Chemicals, chemical products and } \\
\text { Pharmaceuticals }\end{array}$ & 43 & 10.78 \\
\hline
\end{tabular}




\begin{tabular}{|l|l|l|l|}
\hline 4 & Other manufacturing & 30 & 7.52 \\
\hline 5 & Other non-metallic mineral products & 28 & 7.02 \\
\hline 6 & Motor vehicles, trailers and auto parts & 22 & 5.51 \\
\hline 7 & Fuel and Energy & 28 & 7.02 \\
\hline 8 & $\begin{array}{l}\text { Information, Communication \& transport } \\
\text { Services }\end{array}$ & 13 & 3.26 \\
\hline 9 & Coke and refined petroleum products & 9 & 2.26 \\
\hline 10 & Paper, paperboard and products & 9 & 2.26 \\
\hline 11 & Electrical machinery and apparatus & 8 & 2.00 \\
\hline 12 & Other services activities & 10 & 2.51 \\
\hline & Total & 399 & 100 \\
\hline
\end{tabular}

According to table 1 there are 38.85 percent firms belong to the major textile sector of Pakistan. Food and chemical economic groups stood at the second and third position respectively. Services sector belongs to the smallest economic group of the above mentioned distribution.

Table 2 is providing the descriptive statistics of the sample data. To analyze the influence of trade credit in overall volume of balance sheet of non-financial firms, we have divided the table into different subparts. It has been observed that economic group eleven (Electrical machinery and apparatus) have greater mean of trade credit supply than any other group. It means electrical machinery and apparatus group deals more in credit sales as compare to other groups and on average their investment in account receivables is thirty percent. Economic group seven, eight, ten and twelve holds second and third positions respectively. On the other hand we can say that trade credit supply is lesser use in second and fifth economic group. Variation in economic group seven (Fuel and Energy) and eleven (Electrical machinery and apparatus) has been found more than any other group. It has also been observed that non-financial listed firms are not much interested in receiving goods on credit as compare to granting goods on credit. On average economic group twelve (Other services activities) has more volume of trade credit demand as compare to other economic groups. Manufacturing and non-metallic mineral products also have enough amount of trade credit demand on their balance sheets. Although, on average economic group twelve has greater use of trade credit demand, but it also have greater variation in its data. Economic group ten (Paper, paperboard and products) have lesser variation in the data of trade credit demand.

Table 2: Descriptive statistics

\begin{tabular}{|c|c|c|c|c|c|c|c|c|c|c|}
\hline & \multicolumn{5}{|c|}{ TCS } & \multicolumn{5}{|c|}{ TCD } \\
\hline & Mean & Min & Max & Var & $\mathrm{SD}$ & Mean & Min & Max & Var & SD \\
\hline EG1 & 0.11 & 0.00 & 0.76 & 0.01 & 0.11 & 0.04 & 0.00 & 0.52 & 0.01 & 0.09 \\
\hline EG2 & 0.03 & 0.00 & 0.11 & 0.00 & 0.03 & 0.04 & 0.00 & 0.40 & 0.01 & 0.08 \\
\hline EG3 & 0.10 & 0.00 & 0.51 & 0.01 & 0.11 & 0.06 & 0.00 & 0.34 & 0.01 & 0.08 \\
\hline EG4 & 0.07 & 0.00 & 0.59 & 0.01 & 0.10 & 0.10 & 0.00 & 0.62 & 0.02 & 0.15 \\
\hline EG5 & 0.04 & 0.00 & 0.22 & 0.00 & 0.05 & 0.10 & 0.00 & 0.64 & 0.01 & 0.12 \\
\hline EG6 & 0.10 & 0.00 & 0.64 & 0.01 & 0.12 & 0.09 & 0.00 & 0.80 & 0.03 & 0.16 \\
\hline EG7 & 0.26 & 0.00 & 0.85 & 0.04 & 0.20 & 0.08 & 0.00 & 0.51 & 0.02 & 0.13 \\
\hline EG8 & 0.13 & 0.01 & 0.44 & 0.01 & 0.10 & 0.07 & 0.00 & 0.68 & 0.02 & 0.14 \\
\hline EG9 & 0.10 & 0.01 & 0.35 & 0.01 & 0.08 & 0.07 & 0.00 & 0.31 & 0.01 & 0.08 \\
\hline EG10 & 0.13 & 0.00 & 0.43 & 0.01 & 0.09 & 0.02 & 0.00 & 0.09 & 0.00 & 0.03 \\
\hline EG11 & 0.30 & 0.05 & 0.70 & 0.03 & 0.18 & 0.05 & 0.00 & 0.15 & 0.00 & 0.04 \\
\hline EG12 & 0.13 & 0.00 & 0.64 & 0.02 & 0.15 & 0.15 & 0.00 & 0.58 & 0.04 & 0.19 \\
\hline \multirow{2}{*}{\multicolumn{3}{|c|}{ Inventorv (INV) }} & Mean & \multicolumn{2}{|c|}{ Minimum } & \multicolumn{2}{|c|}{ Maximum } & \multicolumn{3}{|c|}{ Std. Deviation } \\
\hline & & Inventory (INV) & 0.1901 & \multicolumn{2}{|c|}{0.0000} & \multicolumn{2}{|c|}{0.7200} & \multicolumn{3}{|c|}{0.1471} \\
\hline \multicolumn{3}{|c|}{$\begin{array}{l}\text { Price Discrimination } \\
\text { (PD) }\end{array}$} & 0.0143 & \multicolumn{2}{|c|}{-0.0400} & \multicolumn{2}{|c|}{0.0900} & \multicolumn{3}{|c|}{0.0407} \\
\hline \multicolumn{3}{|l|}{ TURN } & -18.2699 & \multicolumn{2}{|c|}{-12.7100} & \multicolumn{2}{|c|}{27.0100} & \multicolumn{3}{|c|}{8.0966} \\
\hline \multicolumn{3}{|l|}{ SIZE } & 3.8717 & \multicolumn{2}{|c|}{-2.6400} & \multicolumn{2}{|c|}{7.6700} & \multicolumn{3}{|c|}{1.3416} \\
\hline
\end{tabular}




\begin{tabular}{|l|c|c|c|c|}
\hline Liquidity (LIQ) & 0.0525 & 0.0000 & 0.9000 & 0.0932 \\
\hline GDP & 8.5929 & 8.4200 & 8.8000 & 0.1139 \\
\hline Sales Growth (SG) & 0.1465 & -1.5600 & 9.4600 & 0.7753 \\
\hline
\end{tabular}

By looking at the minimum and maximum values of the other independent variables, they are indicating that extreme values do not exist in the ratios of these variables. Moreover we can observe that there is not a pronounced variation in data. TURN have a negative mean and greater variation than any other variable. Price discrimination and Liquidity have lesser variation in their data sets.

To check the correlation among variables a Pearson correlation test has been conducted. Table 3 is containing the correlation matrix for variables. Trade credit supply is the ratio of account receivables to sales and it has a positive correlation with TCD, NTC, SG and GDP. TCS have negative correlation with INV, LIQ, PD, SIZE and TURN. TCD is the ratio of account payables to sales. It has a negative correlation with all variables except LIQ and SG. NTC is ratio of account receivable minus accounts payables to sales. It has greater correlation with TCS and TCD, because by definition it has derived from these two variables. It has positive correlation with PD, SIZE and GDP. It has a negative correlation with INV, LIQ, SG and TURN. INV is stand for inventory and can be calculated as inventory to total sales. It has positive correlation with all variables except LIQ. LIQ is liquidity ratio can be measured as firm liquid assets to total assets. Liquidity has a positive correlation with PD, SG and TURN but negative with SIZE and GDP.

Table 3: Correlation Matrix

\begin{tabular}{|c|c|c|c|c|c|c|c|c|c|}
\hline & TCS & TCD & INV & LIQ & PD & SG & SIZE & TURN & GDP \\
\hline TCS & 1 & & & & & & & & \\
\hline TCD & .031 & 1 & & & & & & & \\
\hline INV & -.115 & -.099 & 1 & & & & & & \\
\hline LIQ & -.073 & .053 & -.073 & 1 & & & & & \\
\hline PD & -.029 & -.144 & .034 & .055 & 1 & & & & \\
\hline SG & .127 & .091 & .006 & .068 & -.076 & 1 & & & \\
\hline SIZE & -.153 & -.186 & .294 & -.065 & .027 & -.096 & 1 & & \\
\hline TURN & -.197 & -.007 & .079 & .029 & -.046 & .063 & -.028 & 1 & \\
\hline GDP & .064 & -.175 & .037 & -.230 & .294 & -.214 & .179 & -.119 & 1 \\
\hline
\end{tabular}

Price discrimination (PD) is operating margin to sales. Price discrimination has negative correlation with SG and TURN but positive with SIZE and GDP. Sales growth is calculated as current year sales minus previous year sales divided by previous year sales. SG has a positive correlation with TURN but negative with SIZE and GDP. SIZE can be calculated as natural log of book value of assets. SIZE has a positive correlation with GDP but negative with TURN. TURN is a proxy for product quality and calculated as sales over assets deducting receivables. TURN is negatively correlated with GDP. By looking at the magnitude of the correlations among variables, we can observe that no variable have greater correlation with any other variable which means variables do not have the problem of multicollinearity.

In order to check the violation of ordinary least square assumptions we have performed different tests to check the problems of multicollinearity, autocrrelation and heteroskedasticity. By looking at the variance inflation factor (VIF) it appears that problem of multicollinearity does not exist because all variables have VIF less than five. Values of Durbin Watson indicate that data selected for analysis do not carry out any problem of autocorrelation. To check the problem of heteroskedasticity we draw standard residuals against standard predicted and found them random.

2 Econometric Methodology

As cross sectional and time series data posed some problems, in order to overcome some problems, and panel data estimations tries to capture these problems. By using a large number of observations make a researcher able to acquire more efficient inferences (Wang 2009) and help in to reduce the problem of multicollinearity (Asimakopoulos et al. 2009). According to Wang (2009) panel data allow us to seize the variation in time and cross section components. 
To check the strength of the results we have applied three models as Pooled OLS, Fixed Effects and Random Effects Model. Nobody till date has analyzed the determinants of trade credit in this proper way of analyzing. Rationality behind using these three models is to reach at more suitable explanation of the results from the given data. We have analyzed the hypotheses after selecting the more appropriate regression method.

Basic regression method for pooled data is pooled ordinary least square, which tries to minimize the sum of squared residuals. Since, simple linear regression model for panel data can be written as

$$
Y_{i t}=\alpha+\beta X_{i t}+u_{i t}
$$

Where, $\mathrm{i}$ is representing ith firm at time t. $\mathrm{Y}$ is dependent variable and $\mathrm{X}$ is an independent variable. $\mathrm{u}$ is an error term. Equation one based on the postulation that $a$ is equal for all cross sections. By introducing some heterogeneity in equation one allows us for identical $\alpha$ for all cross sections. Then, equation one can be written as:

$$
Y_{i t}=\alpha_{i}+\beta X_{i t}+u_{i t}
$$

Where, ai is different for all cross sections. Now, this linear panel data model can assess by using common constant method, fixed effects method and random effects method.

Common constant method also known as pooled OLS method, works on the assumption that the given data set is priori homogeneous. It means this model estimate a single constant ( $\alpha$ ) for all given cross sections. On the other hand fixed effects model permit different constants for all sections. After allowing different constants for different sections it includes a separate dummy for all sections. That is why it is also known as least square dummy variable estimator. General form of the least square dummy variable is as follows:

$$
\mathrm{Y}_{\mathrm{it}}=\alpha_{\mathrm{i}}+\beta_{1} \mathrm{X}_{1 \mathrm{it}}+\cdots+\beta_{\mathrm{k}} \mathrm{X}_{\mathrm{kit}}+\mathrm{u}_{\mathrm{it}}
$$

Equation three can be written in matrix equation as:

$$
\mathrm{Y}=\mathrm{D} \alpha+\mathrm{X} \beta+\mathrm{u}
$$

Where, dummy variable sanctions to take different constants for different groups.

and

$$
\mathrm{Y}=\left[\begin{array}{c}
\mathrm{y}_{1} \\
\mathrm{y}_{2} \\
\vdots \\
\mathrm{y}_{\mathrm{N}}
\end{array}\right]_{\mathrm{NT} \times 1}, \mathrm{D}=\left[\begin{array}{cccc}
\mathrm{i}_{\mathrm{T}} & 0 & \cdots & 0 \\
0 & \mathrm{i}_{\mathrm{T}} & \cdots & 0 \\
\vdots & \vdots & \vdots & \vdots \\
0 & 0 & \cdots & \mathrm{i}_{\mathrm{T}}
\end{array}\right]_{\mathrm{NT} \times \mathrm{N}}, \mathrm{X}=\left[\begin{array}{cccc}
\mathrm{x}_{11} & \mathrm{x}_{12} & \cdots & \mathrm{x}_{1 \mathrm{k}} \\
\mathrm{x}_{21} & \mathrm{x}_{22} & \cdots & \mathrm{x}_{2 \mathrm{k}} \\
\vdots & \vdots & \vdots & \vdots \\
\mathrm{x}_{\mathrm{N} 1} & \mathrm{x}_{\mathrm{N} 2} & \cdots & \mathrm{x}_{\mathrm{Nk}}
\end{array}\right]_{\mathrm{NT} \times \mathrm{k}}
$$

$$
\alpha=\left[\begin{array}{c}
\alpha_{1} \\
\alpha_{2} \\
\vdots \\
\alpha_{\mathrm{N}}
\end{array}\right]_{\mathrm{N} \times 1}, \beta=\left[\begin{array}{c}
\beta_{1} \\
\beta_{2} \\
\vdots \\
\beta_{\mathrm{k}}
\end{array}\right]_{\mathrm{k} \times 1}
$$

Before making any analysis the question arises whether we should allow for different constants for different sections. F test is a measure that can be used to assess whether we should use fixed effects method or pooled ordinary least square method, which allows for common constant. In this analysis we have developed the following hypothesis

Ho: $\alpha 1=\alpha_{2}=\alpha_{3}=\ldots \ldots . . .=\alpha$ n (Pooled OLS is appropriate)

H1: Fixed effects model is appropriate

By using following standard formula of F-statistic we have calculated F-estimated.

$\mathrm{F}=\frac{\mathrm{R}_{\mathrm{FE}}^{2}-\mathrm{R}_{\mathrm{CC}}^{2} / \mathrm{N}-1}{1-\mathrm{R}_{\mathrm{FE}}^{2} / \mathrm{NT}-\mathrm{N}-\mathrm{K}} \sim \mathrm{F}(\mathrm{N}-1, \mathrm{NT}-\mathrm{N}-\mathrm{K})$

Where, R2CC is coefficient of determination of common constant model and R2FE is coefficient of determination of fixed effect model. Lesser value of F-critical than F-calculated would leads to reject the null hypothesis. F-calculated for trade credit supply is 16.8813 which is significantly greater than F-critical that is 1.1048. On the basis of this evidence we can reject our null hypothesis. It means fixed effects model is more appropriate for trade credit supply than pooled ordinary least square. By adopting same procedure for trade credit demand we have found that F-calculated (5.1401) is significantly greater than F-critical (1.1044) lead towards making decision in favor of fixed effects model.

Random effect model based on the assumption that constants of each section do not remain fixed. It assumes that constants of each group are random parameters. This variation in these constants originate from 


$$
\alpha_{i}=\alpha+v_{i}
$$

Where vi is standard random variable which have expected value equal to zero. In general, random effects model can be offered in the following form

$$
\begin{aligned}
& Y_{i t}=\left(\alpha+v_{i}\right)+\beta_{1} X_{1 i t}+\cdots+\beta_{k} X_{k i t}+u_{i t} \\
& Y_{i t}=\alpha+\beta_{1} X_{1 i t}+\cdots+\beta_{k} X_{k i t}+\left(v_{i}+u_{i t}\right)
\end{aligned}
$$

To measure the difference between fixed effects and random effects models Hausman test can be used (Ahn and Moon, 2001).

$$
\mathrm{H}=\left(\beta^{\wedge \mathrm{FE}}-\beta^{\wedge \mathrm{RE}}\right)^{\prime}\left[\operatorname{var}\left(\beta^{\wedge \mathrm{FE}}\right)-\operatorname{var}\left(\beta^{\wedge \mathrm{RE}}\right)\right]^{-1}\left(\beta^{\wedge \mathrm{FE}}-\beta^{\wedge \mathrm{RE}}\right) \sim \mathrm{x}^{2}(\mathrm{k})
$$

It is applied to make the selection between the use of fixed effects or random effects models. This test based on the following hypothesis

Ho: Random effects model is appropriate

H1: Fixed effects model is appropriate

After applying the Hausman test we have found the following results.

Table 4: Hausman Test

\begin{tabular}{|c|l|c|c|c|}
\hline & \multicolumn{1}{|c|}{ Test Summary } & Chi Square statistic & Chi square df. & Prob. \\
\hline TCS & Cross section random & 14.4749 & 7 & 0.0434 \\
\hline TCD & Cross section random & 8.6417 & 4 & 0.0507 \\
\hline
\end{tabular}

Significant values are evidently suggesting that we should reject our null hypothesis and accept alternative hypothesis. On the basis of above arguments we are able to use fixed effects model to capture the effects of firm specific and macroeconomic factors on trade credit.

Equation 11 is used to estimate the factors effecting trade credit supply by using fixed effects model.

$$
\begin{aligned}
\frac{\mathrm{AR}_{\text {it }}}{\text { Sales }_{\text {it }}}=\alpha_{\mathrm{i}}+ & \beta_{1} \frac{\text { Inventory }_{\text {it }}}{\text { Sales }_{\text {it }}}+\beta_{2} \frac{\text { Operating Margin }_{\text {it }}}{\text { Sales }_{\text {it }}}+\beta_{3}\left[\left(\frac{\text { Sales }_{\text {it }}}{\text { Total Assets }_{\text {it }}}\right)-\left(\mathrm{AR}_{\mathrm{it}}\right)\right] \\
& +\beta_{4} \operatorname{Ln}\left(\text { Book value of assets }_{\text {it }}\right)+\beta_{5} \frac{\text { Liquid Assets }_{\text {it }}}{\text { Total Assets }_{\text {it }}}+\beta_{6} \log (\mathrm{GDP}) \\
& +\beta_{7}\left(\frac{\text { Sales of current year }- \text { Sales of previous year }}{\text { Sales of previou year }}\right)+\mathrm{e}_{\mathrm{it}}
\end{aligned}
$$

The following equation 12 is used to estimate the factors effecting trade credit demand by using fixed effects model.

$$
\begin{aligned}
\frac{\text { AP }_{\text {it }}}{\text { Sales }_{\text {it }}}=\alpha_{i}+ & \gamma_{1}\left(\text { Book value of assets }_{\text {it }}\right)+\gamma_{2} \frac{\text { Liquid Assets }_{\text {it }}}{\text { Total Assets }}+\gamma_{3} \log (\text { GDP }) \\
& +\gamma_{4}\left(\frac{\text { Sales of current year }- \text { Sales of previous year }}{\text { Sales of previou year }}\right)+u_{i t}
\end{aligned}
$$

\section{Results}

Table 5 and 6 are showing the effects of different firm specific and macroeconomic factors on trade credit. In both tables, column I, II and III are showing the results of pooled ordinary least square, fixed effects and random effects model respectively. Most of our results are in line with the previous findings of different studies on determinants of trade credit.

In table 5 the results of fixed effects and random effects model for inventory variable turn out to be highly significant with negative mark of coefficient. On the other hand pooled ordinary least square is indicating towards the negative but not significant relationship of inventory with trade credit supply. According to the results of fixed effects model, inventory to sales ratio is significantly related to trade credit supply. Negative sign of coefficient is indicating that one unit increase in inventory would lead towards $\mathbf{1 5 . 7 8}$ percent decrease in trade credit supply. In order to increase sales non-financial firms in Pakistan tries to grant more credit on sales which leads towards the decrease in inventory. This statement turned our direction towards the important motive of inventory management. Our result for inventory is in line with the empirical findings of (Vaidya 2011) and proves our H3a hypothesis. 
In table $5 \mathrm{PD}$ is price discrimination and it is calculated as operating margin divided by sales. Rise in operating margin is an indication for suppliers that they can enhance their cash flows by allowing more goods on credit to their needy customers (Niskanen and Niskanen 2006). Monopolists can practice trade credit as an instrument to differentiate price among those customers which pay early and get discounts than those which cannot. After testing price discrimination variable in all three models, it appears with negative sign of coefficient and remains insignificant. Even though our outcome for price discrimination is against the theory of price discrimination proposed by Petersen and Rajan (1997) but on other hand in line with the empirical findings of Niskanen and Niskanen (2006). This insignificance is might be outstanding due to the fact that not a single non-financial firm in Pakistan has a monopoly power to differentiate the price.

TURN is used as proxy for quality of the product being offered on credit as stated by GarciaTeruel and Martinez-Solano (2010a). They further argue that lower values of turn represent high quality of products and hence, firms with high quality products would grant more trade credit to convey the quality to their customers. According to table 5 TURN is also in line with hypothesis confirming a negative relationship with trade credit supply and it is significant at $\mathrm{p}$-value $<0.01$. The empirical findings of Li (1997) also support the negative and significant relationship of TURN with accounts receivables. This is the only variable that is mutually significant in all three models estimated.

SIZE is calculated as natural log of book value of assets. In table 5 we have found that size of the firm is significant and negatively related to trade credit supply in pooled ordinary least square and fixed effects methods. This shows that large firms do not carry out credit sale transactions. These results confirm the empirical findings of Wilson \& Summers (2002) who state that young and small firms use trade credit supply as a means to assure their quality and build their reputation among potential customers in order to increase their market share. Also the empirical literature states that as large firms have already built their reputation in the market and their customers are well aware and satisfied with their quality hence they offer less trade credit to customers (Long et al. 1993).

Table 5: Determinants of Trade Credit Supply

\begin{tabular}{|c|c|c|c|}
\hline & $\mathrm{I}$ & II & III \\
\hline Inventory (INV) & $\begin{array}{l}-0.0253 \\
(0.0286)\end{array}$ & $\begin{array}{c}-0.1578^{* * *} \\
(0.0361)\end{array}$ & $\begin{array}{c}-0.0868^{* * *} \\
(0.0305)\end{array}$ \\
\hline Price Discrimination (PD) & $\begin{array}{l}-0.0173 \\
(0.1142)\end{array}$ & $\begin{array}{l}-0.0891 \\
(0.0581)\end{array}$ & $\begin{array}{l}-0.0658 \\
(0.0646)\end{array}$ \\
\hline TURN & $\begin{array}{c}-1.73 \mathrm{E}-06^{* * *} \\
(5.91 \mathrm{E}-07)\end{array}$ & $\begin{array}{c}-3.61 \mathrm{E}-06^{* * *} \\
(4.01 \mathrm{E}-07)\end{array}$ & $\begin{array}{c}-1.90 \mathrm{E}-06^{* * *} \\
(4.71 \mathrm{E}-07)\end{array}$ \\
\hline SIZE & $\begin{array}{l}-0.0110^{* * * *} \\
(0.0030)\end{array}$ & $\begin{array}{l}-0.0100^{* *} \\
(0.0043)\end{array}$ & $\begin{array}{l}-0.0057 \\
(0.0038)\end{array}$ \\
\hline Liquidity (LIQ) & $\begin{array}{l}-0.0707^{*} \\
(0.0418)\end{array}$ & $\begin{array}{c}-0.1167^{* * * *} \\
(0.0355)\end{array}$ & $\begin{array}{l}-0.0568^{*} \\
(0.0314)\end{array}$ \\
\hline Sales Growth (SG) & $\begin{array}{l}0.0459^{* * * *} \\
(0.0080)\end{array}$ & $\begin{array}{l}0.0173^{* * * *} \\
(0.0032)\end{array}$ & $\begin{array}{c}0.0336^{* * * *} \\
(0.0050)\end{array}$ \\
\hline GDP & $\begin{array}{c}0.1397^{* * *} \\
(0.0442)\end{array}$ & $\begin{array}{c}0.10592^{* * *} \\
(0.0246)\end{array}$ & $\begin{array}{c}0.0808^{* * *} \\
(0.0262)\end{array}$ \\
\hline Constant & $\begin{array}{l}-1.0597^{*} \\
(0.3776)\end{array}$ & $\begin{array}{c}-0.6968^{* * *} \\
(0.1993)\end{array}$ & $\begin{array}{c}-0.5635^{* *} \\
(0.2245)\end{array}$ \\
\hline Adjusted R-square & 0.0887 & 0.7317 & 0.1176 \\
\hline $\begin{array}{l}\text { F-statistic } \\
\text { Prob(F-statistic) }\end{array}$ & $\begin{array}{c}9.4881 \\
(0.0000)\end{array}$ & $\begin{array}{c}18.5705 \\
(0.0000)\end{array}$ & $\begin{array}{c}12.622 \\
(0.0000)\end{array}$ \\
\hline Akaike info criterion & -1.8694 & -2.5173 & \\
\hline Schwarz criterion & -1.8115 & -1.7733 & \\
\hline Durbin-Watson stat & 0.5111 & 1.4879 & 0.4882 \\
\hline
\end{tabular}

Standard errors are reported in parentheses. ${ }^{* * *}$ and ${ }^{* *}$ are showing the significance at $1 \%$ and $5 \%$ level of significance respectively. 
The negative sign of firm size with trade credit supply can also be justified in our study by the Diversion Value Theory put forward by Burkart and Ellignsen (2004). They argue that buyers may divert bank loans instead of purchasing inputs for their projects. Buyers may take inputs on credit and may complete their projects rather having bank funding. Moreover, it is useful for the sellers to extend trade credit as they may use the accounts receivables as collateral for bank financing. This theory has been used by Giannetti et al. (2003) in providing evidence that the producers of standardize goods have less incentive to offer trade credit than the producers of differentiated goods. In case of repayment failure repossessed goods are more valuable to the supplier than to the bank and this is more pronounced in the case of a differentiated product than a standardize one. As our sample consists of the firms which are listed at Karachi Stock Exchange and are producing standardize goods. We may have got a positive relationship of size of the firm with the trade credit supply if we have included the producers of differentiated goods not listed at Karachi Stock Exchange. Thus the product nature could prove to be a good avenue for future research in context of Pakistan. As for as this study is concerned we will not reject our hypothesis of having a significant relationship between firm size and trade credit supply. According to table 6 it is found that size of the non-financial firms is inversely related to trade credit demand.

In table 5 and 6 LIQ stand for liquidity and calculated as liquid assets divided by total assets. In all three models estimated for factors effecting trade credit it is found that liquidity is inversely related to trade credit supply and positively with trade credit demand. Although the strength of significance is high in case of fixed effects model, but we have also found liquidity significant in all three models estimated. The results are in line with the inventory management model which suggests the significant relationship between liquidity and trade credit. The inventory management model developed by Bougheas et al. (2009) speaks of our two variables naming liquidity and size of the firm in determining the level of trade credit supply. They argue that producers produce goods either to sell finished goods or to hold them in inventory at cost and thus play a role in the credit chain as middle men. This could be explained by the fact that the producers which are not certain about their products demand would be at ease to offer trade credit to customers with financial constraints. This would result in enhancing sales rather than accumulate costly inventories. This mechanism is only appropriate for firms facing liquidity issues in managing their own obligations which they could resolve by extending trade credit to its customer. Thus having twofold benefits generating cash inflows and also enhancing product demand. Thus firms with higher liquidity issues would extend more trade credit than those with enough liquidity to manage their affairs. Hence, we will reject our null hypothesis regarding relationship between liquidity and trade credit supply.

Table 6: Determinants of Trade Credit Demand

\begin{tabular}{|l|c|c|c|}
\hline SIZE & I & II & III \\
\hline Liquidity (LIQ) & $\begin{array}{c}-0.0148^{* *} \\
(0.0037)\end{array}$ & $\begin{array}{c}-0.0195^{*} \\
(0.0100)\end{array}$ & $\begin{array}{c}-0.0166^{* * *} \\
(0.0049)\end{array}$ \\
\hline Sales Growth (SG) & $\begin{array}{c}0.1187^{* *} \\
(0.0527)\end{array}$ & $\begin{array}{c}0.1937^{* * *} \\
(0.0614)\end{array}$ & $\begin{array}{c}0.1523^{* *} \\
(0.0535)\end{array}$ \\
\hline GDP & $\begin{array}{c}0.0507^{* *} \\
(0.0101)\end{array}$ & $\begin{array}{c}0.0511^{* * *} \\
(0.0096)\end{array}$ & $\begin{array}{c}0.0502^{* * *} \\
(0.0090)\end{array}$ \\
\hline Constant & -0.0459 & 0.0346 & 0.0038 \\
& $(0.0552)$ & $(0.0492)$ & $(0.0476)$ \\
\hline Adjusted R-square & 0.5017 & -0.1426 & 0.0836 \\
\hline F-statistic & $(0.4720)$ & $(0.4210)$ & $(0.4073)$ \\
Prob(F-statistic) & 0.0866 & 0.5228 & 0.0829 \\
\hline Akaike info criterion & 15.6597 & 4.0266 & 14.971 \\
\hline Schwarz criterion & $(0.0000)$ & $(0.0000)$ & $(0.0000)$ \\
\hline Durbin-Watson stat & -1.3872 & -1.6124 & \\
\hline Standard & -1.3514 & -0.6681 & 1.2424 \\
\hline
\end{tabular}

Standard errors are reported in parentheses. ${ }^{* * *}$ and ${ }^{* *}$ are showing the significance at $1 \%$ and $5 \%$ level of significance respectively. 
SG stands for sales growth. It is considered as ratio of annual sales growth. Nature of trade credit strategy depends on aimed growth rates. On the basis of two variables namely, Time and Credit terms are considered as driving force for any credit policy (Niskanen and Niskanen 2006). Firms which offer higher discount and time for repayment are consider as firm with higher objective of growth rate and vice versa. To offer more goods on credit require acquiring their supplies from suppliers in time. It might be possible that they believe in to get raw material and other goods on credit. Firms with greater objective of growth rate it might be possible that they will extend more trade credit and also interested in receiving goods on credit. On the basis of above mentioned justifications we can say that sales growth should be positively rated to trade credit supply and demand. As per our expectations we have found a positive and significant relationship between sales growth and trade credit. In table 5 and 6 all three models estimated for trade credit supply and demand are validating this opinion.

GDP is Gross Domestic Product which is calculated as taking log of real values of gross domestic product for Pakistan in given periods. In table 5 the results of three models estimated confirms our hypothesis based on positive and significant relationship between trade credit supply and gross domestic product. On the other hand in table 6 results for demand side relationship found to be insignificant and this insignificance for gross domestic product remains identical in three columns.

We have not included the first three variables estimated for trade credit supply because they were particularly related to trade credit supply. On the basis of different parameters we can compare our estimated models. First thing that we can observe is the value of adjusted R square. In table 5 and 6 values of adjusted $\mathrm{R}$ square for fixed effects model are significantly greater than pooled ordinary square method and random effects method. On the basis of Akaike Information Criterion and Shwartz Information Criterion we can also consider fixed effects as superior than other two models. Value of Durbin Watson is also better for fixed effects model. On the basis of all these parameters made for comparison of models estimated we can finally propose that fixed effects model is most appropriate in finding the factors affecting the level of trade credit in Pakistan.

\section{Conclusion}

The study adds to the literature by analyzing the determinants of trade credit in context of Pakistan. Many studies has called for this literature gap that trade credit practices should be studied in different cultures in order to have insights into the different patterns prevailing across the nations (Solano et al. 2012). Thus this research has tried to sort the supply and demand side of trade credit prevailing in Pakistan. Furthermore, we have used the variable of liquidity which has not been previously used by other authors expect for the ones who put forward its theory. Results give strength to the inventory management model postulated by Bougheas et al. (2009) that liquidity is important in determining the level of trade credit. The study has found that firms with greater size enhance their sales without getting involved in credit transactions. It is also observed that the firms with low quality products have no need to get involved in credit transaction. As they are scared from losing their customers after measuring the quality of their products so they grant less trade credit. Sales growth remain positive and significant in both cases which suggest that firm with higher objective to achieve higher growth rate are more interested to get involved in trade credit transactions. It is also found that firms can save their inventory cost by granting more trade credit. Large firms in Pakistan have no monopoly power to change the price. In case of progress in gross domestic product non-financial firms of Pakistan practices more trade credit.

The study give some important insights to the industry players in a way that the firms may decide on their trade credit patterns while considering the firm specific characteristics. By this we mean that as firms whose products require more time to verify the quality may give extended credit periods in order to build strong relationship with their customers. Further, firms that are facing liquidity issues may take trade credit as a tool in order to build their current assets and this may serve collateral to get bank loan. Last but not the least; trade credit could be used as an inventory management practice as the units that require storage cost could be dealt profitably by issuing them on credit.

For future directions first, it is need to explore more factors effecting trade credit demand in the industrial sectors of Pakistan. Secondly, a very wide part of our economy stays out of research 
area which consists of the non-listed firms and they do not maintain their financial statements in a proper manner. One such research would use primary data from these market players and may bring up the valuable insights in to the trade credit patterns at work.

\section{References:}

1. Ahn, S. C., \& Moon, H. R. (2001). Large-N and Large-T Properties of Panel Data Estimators and the Hausman Test. Paper presented at the 1oth International Conference on Panel Data, Berlin, July 5-6, 2002, International Conferences on Panel Data.

2. Asimakopoulos, I., Samitas, A. \& Papadogonas, T. (2009), Firm-specific and economy wide determinants of firm profitability: Greek evidence using panel data. Managerial Finance, Vol. 35 Iss: 11 pp. 930-939.

3. Beck T., Demirgüc-Kunt A., and Maksimovic V., (2008). Financing patterns around the world: Are small firms different? Journal of Financial Economics 89: 467-487.

4. Bougheas S., Mateut S. \& Mizen P., (2009). Corporate trade credit and inventories: New evidence of a trade-off from accounts payable and receivable. Journal of Banking and Finance 33 (2), 300-307.

5. Boyery M. M. \& Gobert K., (2007). The impact of switching costs on vendor financing. Finance Research Letters 6 (4), 236-241.

6. Burkart M \& Ellingsen T, (2004). In-kind finance: a theory of trade credit. The American Economic Review 94 (3), 569-590.

7. Cheng N. S. \& Pike R., (2003). The trade credit decision: Evidence of UK firms. Managerial and Decision Economics 24 (6) and (7), 419-438.

8. Deloof M \& Jegers M, (1996). Trade credit, product quality, and intragroup trade: some European evidence. Financial Management 25 (3), 33-43.

9. Ferris J. S., (1981). A transactions theory of trade credit use. Quarterly Journal of Economics 96, 243-270.

10. Frank M. Z. \& Maksimovic V., (2004). Trade credit, collateral, and adverse selection. University of Maryland, College Park, USA, Working paper MD 20742.

11. Garcia-Teruel P. J. \& Martinez-Solano P., (2010a). Determinants of trade credit: A comparative study of European SMEs. International Small Business Journal 28 (3), 215-233.

12. Ge, Y., Qiu, J., (2007). Financial development, bank discrimination and trade credit. Journal of Banking and Finance 31, 513-530.

13. Giannetti, M., (2003). Do better institutions mitigate agency problems? Evidence from corporate finance choices. Journal of Financial and Quantitative Analysis 38, 185-212.

14. Guariglia A. \& Mateut S., (2006). Credit channel, trade credit channel, and inventory investment: Evidence from a panel of UK firms. Journal of Banking and Finance 30 (10), 28352856.

15. Jain N., (2001). Monitoring costs and trade credit. The Quarterly Review of Economics and Finance 41 (1), 89-110.

16. Kohler M., Britton E. \& Yates T., (2000). Trade credit and the monetary transmission mechanism. Bank of England, London, Working paper EC2R 8AH.

17. Lee Y. W., StoI J. D., (1993). Product risk, asymmetric information, and trade credit. Journal of Financial and Quantitative analysis 28, 285-300.

18. Li, W., (1997). The impact of economic reform on the performance of Chinese State Enterprises: 1980-1989. Journal of Political Economy 105, 1080-1106.

19. Long M. S., Malitz I. B., Ravid S. A., (1993). Trade Credit, Quality Guarantees, and Product Marketability. Financial Management 22, 117-127.

20. Martinez-Sola, C., García-Teruel, P. J., \& Martinez-Solano, P., (2012). Corporate Cash Holding and Firm Value, Applied Economics, 45 (2), 161- 170

21. Ng C. K., Smith J. K. \& Smith R. L., (1999). Evidence on the determinants of credit terms used in interfirm trade. The Journal of Finance 54 (3), 1109-1129.

22. Niskanen J. \& Niskanen M., (2006). The determinants of corporate trade credit policies in a bank-dominated financial environment: The case of Finnish small firms. European Financial Management 12 (1), 81-102.

23. Ono M., (2001). Determinants of trade credit in the Japanese manufacturing sector. Journal of the Japanese and International Economies 15 (2), 160-177. 
24. Petersen M. A. \& Rajan R. G., (1994). The benefits of lending relationships: Evidence from small business data. The Journal of Finance 49 (1), 3-37.

25. Petersen M. A. \& Rajan R. G., (1997). Trade credit: Theories and evidence. The Review of Financial Studies 10 (3), 661-691.

26. Pike R., Cheng N. S., Cravens K., Lamminmaki D., (2005). Trade credits terms: Asymmetric information and price discrimination evidence from three continents. Journal of Business Finance \& Accounting 32, 1197-1236.

27. Rajan, R., Zingales, L., (1995). What do I know about capital structure? Some evidence from international data. Journal of Finance 50, 1421-1460.

28. Schwartz R. A., (1974). An economic model of trade credit. The Journal of Financial and Quantitative Analysis 9 (4), 643-657.

29. Smith J. K., (1987). Trade credit and informational asymmetry. The Journal of Finance $42(4), 863-872$.

30. Vaidya, R. R., (2012). The Determinants of trade credit: Evidence from Indian manufacturing firms. Working Paper, Indira Gandhi Institute of Development Research.

31. Walker, D., (1991). 'An empirical analysis on financing the small firm', in R. Yazdipmy (ed.), Advances in Small Business Finance (Dordrecht: KluIr Academic, pp. 47-61).

32. Wang, P. (2009). Financial Econometrics, Second edition, Routledge, Taylor \& Francis Group, LONDON AND NEW YORK.

33. Wilner B. S., (2000). The exploitation of relationships in financial distress: The case of trade credit. The Journal of Finance 55 (1), 153-178.

34. Wilson N. \& Summers B., (2002). Trade credit terms offered by small firms: Survey evidence and empirical analysis. Journal of Business Finance \& Accounting 29 (3) \& (4), 317-351. 